\title{
Purification and Characterization of Cold-Adapted Metalloprotease from Deep Sea Water Lactic Acid Bacteria Enterococcus Faecalis TN-9
}

\author{
Qingzhu Yuan (Corresponding author) \& Atsushi Hayashi \\ Central Research Laboratories, Nichinichi Pharmaceutical Co., Ltd.
}

Mie 518-1417, Japan

Tel: 81-595-48-0201Ｅ-mail: yqz5012001@yahoo.com.cn

Yoshihisa Kitamura \& Takashi Shimada

Central Research Laboratories, Nichinichi Pharmaceutical Co., Ltd.

Mie 518-1417, Japan

China-Japan Collaborating Centre for Probiotics Research

Nanjing Medical University

Nanjing, Jiangsu 210029, China

Ren $\mathrm{Na}$

Development \& Service Centre of Cow Industrialization

Xilinhaote, Inner Mongolia 026000, China

Xiao Jin

Animal Hygiene Supervision Place of Inner Mongolia

Huhehaote, Inner Mongolia 010015, China

\begin{abstract}
This paper investigated a 3-step purification and characterization of a protease from Enterococcus faecalis TN-9, a bathypelagic lactic acid bacteria. The purification procedure includes precipitation with $\left(\mathrm{NH}_{4}\right)_{2} \mathrm{SO}_{4}$, then ion-exchange chromatography with DEAE-Sephadex A-25 and DEAE Cellulofine A-500. Native PAGE analysis indicates a single protease band. The molecular weight is $30 \mathrm{kDa}$ by SDS-PAGE analysis, and $69 \mathrm{kDa}$ by gel chromatography analysis. It proves that the optimal temperature for protease reaction is $30^{\circ} \mathrm{C}$, and the optimal $\mathrm{pH}$ is 7.5-8.0. The reaction is stable while $\mathrm{pH}$ is $6.0-9.5$ and temperature is under $45{ }^{\circ} \mathrm{C}$. The relative activity is $6.1 \%$ at $0{ }^{\circ} \mathrm{C}$. The enzyme is totally deactivated with heat treatment at $60{ }^{\circ} \mathrm{C}$ or over. The protease is partially inhibited by EDTA-2Na, $\mathrm{Hg}^{2+}, \mathrm{Cu}^{2+}, \mathrm{Ni}^{2+}$, $\mathrm{Ag}^{2+}, \mathrm{Co}^{2+}$ and Pepstatin A. $\mathrm{Zn}^{2+}$ shows obvious activation to the protease. $\mathrm{K}_{\mathrm{m}}$ and $\mathrm{V}_{\mathrm{max}}$ of purified protease acting on azocasein are $0.098 \%$ and $72 \mathrm{mg} /(\mathrm{h} \cdot \mathrm{mg})$ respectively. This protease is one of gelatinase with $\mathrm{N}$-terminal sequence of VGSEVTLKNS, and shows characteristics of a cold-adapted metalloprotease.
\end{abstract}

Keywords: Deep sea water, Lactic acid bacteria, Cold-adapted enzyme, Metalloprotease, Azocasein

\section{Introduction}

The cold-adapted enzymes from cold-adapted organisms or other microbial life in extreme environments have been widely studied in recent years. Reports are often on cold-adapted enzymes from marine microorganism. Shi et al (2005, p. 258-263; 2006, p. 72-75) separated and purified a strain of cold-adapted enzyme from a psychrophilic bacteria Bacillus cereus SYP-A2-3 acquired from samples collected from glacier. Nushin Aghajari et al (2003, p. 636-647) and Denner E B et al (2001, p. 44-53) isolated a strain of psychrophilic bacteria from samples of Antarctic and studied on the cold-adapted metalloprotease. Miyamoto K et al (2002, p. 416-421) acquired and purified two types of cold-adapted 
metalloprotease (MprI and MprII) from marine microorganism Alteromonas sp. strain O-7. However, we have not found any report on the cold-adapted protease isolated from marine lactic acid bacteria.

Study described in this paper isolated 25 strains of lactic acid bacterium from deep sea water at Toyama Bay of Japanese Sea. Among them Enterococcus faecalis strain TN-9 (Atsushi Hayashi, 2007, p. 58-64) shows liquefying gelatin, fermented and solidified litmus milk, $\beta$-galactosidase activity and other characteristics. Oral administration has been proved safe by sub-acute toxicity study of this bacteria strain in rats (Chie Motonaga, 2007, p. 191-196). Therefore, E. faecalis TN-9 is expected promising in the research and development of health foods containing lactic acid bacteria. Based on above-mentioned results, the study in this paper isolated, purified and characterized the protease from lactic acid bacteria $E$. faecalis TN-9.

\section{Materials and methods}

\subsection{Materials and equipments}

Bacteria stain: lactic acid bacteria E. faecalis strain TN-9, stored and provided by Nichinichi Pharmaceutical Co., Ltd; Lactobacilli MRS Broth from USA; Hinute SMP provided by Fuji Oil Co. of Japan; Azocasein from Sigma of USA; DEAE-Sephadex A-25 from Pharmacia of Sweden; DEAE-Cellulofine A-500 and Toyopearl HW-55s provided by Chisso of Japan; standard protein provided by Wako of Japan; and other commonly used reagents made in Japan. Key instruments: U-2000 spectrophotometer from Hitachi of Japan and KUBOTA 7780 centrifuger from Kubota of Japan.

\subsection{Methodology}

\subsubsection{Culture of strain and collection of culture media}

\section{(1) Culture medium}

Take MRS agar plate as solid culture media. Liquid culture media is a mixture of A, B and C, where A is composed of $1.5 \mathrm{~g}$ Hinute SMP, $2.4 \mathrm{~g}$ D-Glucose, $0.2 \mathrm{~g} \mathrm{NaCl}$ and $70 \mathrm{ml}$ distilled water; $\mathrm{B}$ is composed of $18.0 \mathrm{~g} \mathrm{~K}_{2} \mathrm{HPO}_{4}$ and $100 \mathrm{ml}$ distilled water; $\mathrm{C}$ is composed of $0.05 \mathrm{~g} \mathrm{FeSO}_{4} \cdot 7 \mathrm{H}_{2} \mathrm{O}, 0.58 \mathrm{~g} \mathrm{MgSO}_{4} \cdot 7 \mathrm{H}_{2} \mathrm{O}, 0.03 \mathrm{~g} \mathrm{MnSO}_{4} \cdot 5 \mathrm{H}_{2} \mathrm{O}, 0.10 \mathrm{~g} \mathrm{ZnSO}_{4} \cdot 7 \mathrm{H}_{2} \mathrm{O}$ and $100 \mathrm{ml}$ distilled water. Begin by formulating $\mathrm{A}$ and $\mathrm{B}$, in turn autoclaving at $121{ }^{\circ} \mathrm{C}$ for $15 \mathrm{~min}$, then sterilize $\mathrm{C}$ by sterilizing filter (DISMIC-25CS/0.45 $\mu \mathrm{m}$, made in Toyo of Japan), finally mix A, B and C at the ratio of 7:2:1 in aseptic environment, ready for culture of strain.

(2) Culture of strain and collection of culture media

On the MRS medium, cut marker lines on the $-80{ }^{\circ} \mathrm{C}$ stored bacteria strain, culture the slides at $30{ }^{\circ} \mathrm{C}$ for $48 \mathrm{~h}$. Select and inoculate the independent bacterial colonies into $50 \mathrm{ml}$ the above-mentioned liquid medium. After static culture at $30{ }^{\circ} \mathrm{C}$ for $18 \mathrm{~h}$, transfer it into $800 \mathrm{ml}$ the same liquid medium to have the second static culture at $30{ }^{\circ} \mathrm{C}$ for $18 \mathrm{~h}$. Centrifuge at $4{ }^{\circ} \mathrm{C}(12,000 \times \mathrm{g}, 10 \mathrm{~min})$ to collect supernatant as crude enzyme solution for isolating and purifying protease.

\subsubsection{Determination of protease activity}

Protease activity is measured by the TCA-azocasein assay based on the methods proposed by Hagihara B et al (1958, p. 185-194) and Thomas J B et al (1986, p. 139-145). $100 \mu$ protease solution with specific concentration is added into $400 \mu 1.25 \%(\mathrm{w} / \mathrm{v})$ phosphate-buffered saline (100 mM Na-K phosphate buffer with $\mathrm{pH}$ of 7.5, called buffer A); react at $30{ }^{\circ} \mathrm{C}$ for $10 \mathrm{~min}$ (shaking at 170 times per minute) in water bath; adding $1 \mathrm{ml} 10 \%(\mathrm{w} / \mathrm{v})$ trichloroacetic acid (TCA) to stop the reaction; centrifuge $\left(16,000 \times \mathrm{g}, 20 \mathrm{~min}, 10^{\circ} \mathrm{C}\right)$ the resulting product to remove undigested azocasein. The absorbance (A335) of the obtained supernatant is measured at $335 \mathrm{~nm}$ with a spectrophotometer (Hitachi, U-2000). Protease activity is calculated from the amount of L-tyrosine, which is achieved from A335. One unit of protease activity is defined as the amount of enzyme for $1 \mu \mathrm{g}$ of L-tyrosine which is released from the substrate per minute under the above conditions.

\subsubsection{Determination of protein}

Protein is measured by the Lowry process (Lowry O H, 1951, 265-275), with bovine serum albumin (Sigma of USA) as criterion.

\subsubsection{Polyacrylamide gel electrophoresis (PAGE)}

Referring to the method proposed by Reisfeld R A et al (1962, p. 281-283), Native-PAGE is carried out under the following conditions: $2.5 \%(\mathrm{w} / \mathrm{v})$ stacking gel, $7.5 \%(\mathrm{w} / \mathrm{v})$ separation gel $(\mathrm{pH} 4.0)$, alanine-acetic acid $(\mathrm{pH} 4.5)$ as electrolyte bath, anode/cathode reversely-connected NA-1311 Electrolyte Bath (NIHON EIDO Co. Ltd. Tokyo), and electrophoresis at a constant current of $2.5 \mathrm{~mA}$ for $3.5 \mathrm{~h}$ per column. Referring to the method proposed by Weber $\mathrm{K}$ and Osborn M (1969, p. 4406-4412), SDS-PAGE is carried out under following conditions: $7.5 \%$ (w/v) polyacrylamide gel and $0.10 \%(\mathrm{w} / \mathrm{v})$ SDS-0.10 M phosphate buffer ( $\mathrm{pH} 7.2)$ as electrolyte bath, electrophoresis at a constant current of 6.0 $\mathrm{mA}$ for $3 \mathrm{~h}$ per column. Use BSA (79,000), Aldolase (42,000), Carbonic Anhydrase (30,000), Trypsin Inhibitor $(20,000)$ and Lysozyme (14,000, from Wako of Japan) as reference standards for molecular weight. Stain for $1 \mathrm{~h} \mathrm{with} 0.25 \%(\mathrm{w} / \mathrm{v})$ 
Coomassie Brilliant Blue R-250 solved in the mixture of ethanol, acetic acid and deionized water at the ratio of 9:2:9; destain for $1 \mathrm{~h}$ with the mixture of ethanol, acetic acid and deionized water at the ratio of 25:8:65, further with the mixture of ethanol, acetic acid and deionized water at the ratio of 10:15:175.

\subsubsection{Gel chromatography}

Gel chromatography is carried out at $20 \mathrm{ml} / \mathrm{h}$ by using Toyopearl HW-55s column $(25 \times 900 \mathrm{~mm})$ and buffer A containing $0.2 \mathrm{M} \mathrm{NaCl}$ as eluent. Reagents and kits for molecular weight measurement: Ferritin (440 kDa), Catalase $(240 \mathrm{kDa}), \gamma$-globulin $(160 \mathrm{kDa})$, Bovine serum albumin $(67 \mathrm{kDa})$ and Ovalbumin (43 kDa, from Wako of Japan).

\subsubsection{Isolation and purification of enzyme}

Collect supernatant as crude enzyme by centrifuging 3,200 ml culture medium at $12,000 \times \mathrm{g}, 4^{\circ} \mathrm{C}$ for $10 \mathrm{~min}$. Slowly add $\left(\mathrm{HN}_{4}\right)_{2} \mathrm{SO}_{4}$ powder of saturation $0-60 \%(\mathrm{w} / \mathrm{v})$; stir and sediment for $30 \mathrm{~min}$. Centrifuge the mixture and have the sediment resolved in $40 \mathrm{ml} 100 \mathrm{mM}$ Tris-HCl buffer (buffer B, pH 7.5). The resulting filtrate from semi-permeable membrane is forced through buffer B-balanced DEAE-Sephadex A-25 column $(26 \times 180 \mathrm{~mm})$; uncombined protein is then removed by washing with $450 \mathrm{~mL}$ buffer B; obtained product is finally eluted with $720 \mathrm{ml}$ buffer B at $50 \mathrm{ml} / \mathrm{h}$ (elution gradient is $0 \rightarrow 2.5 \mathrm{M} \mathrm{NaCl})$. Determine protease activity and protein amount of each fraction $(6.0 \mathrm{ml} /$ tube), collect the fractions with high protease activity, apply buffer A-balanced DEAE-Cellulofine A-500 column $(26 \times 180 \mathrm{~mm})$ after dialysis by buffer A for $24 \mathrm{~h}$ (change buffer at the $3^{\text {rd }}$ hour and the $9^{\text {th }}$ hour from the beginning of dialysis), remove other proteins by rinsing with $450 \mathrm{~mL}$ buffer A, then elute with $720 \mathrm{ml}$ buffer $\mathrm{A}$ at $40 \mathrm{ml} / \mathrm{h}$ (elution gradient is $0 \rightarrow 2.0 \mathrm{M}$ $\mathrm{NaCl})$. Determine protease activity and protein amount of each fraction $(3.0 \mathrm{ml} /$ tube $)$; collect the fractions with high protease activity. The purified enzyme is obtained by dialysis with buffer A for $24 \mathrm{~h}$.

\subsubsection{Determination of subunit molecular weight}

Using SDS-PAGE, find subunit molecular weight from $R_{\mathrm{f}}-\log \mathrm{M}_{\mathrm{r}}$ chart, wherein $\mathrm{R}_{\mathrm{f}}$ represents relative mobility of standard protein with certain molecular weight $\left(\mathrm{M}_{\mathrm{r}}\right)$ under SDS-PAGE condition.

\subsubsection{Determination of optimal reaction temperature and optimal $\mathrm{pH}$}

The optimal reaction temperature and optimal $\mathrm{pH}$ are found from relative activities of enzyme at different temperature $\left(0-80{ }^{\circ} \mathrm{C}\right)$ and in different buffers of different $\mathrm{pH}$, buffers such as $100 \mathrm{mM}$ acetate solution $(\mathrm{pH} 3.2-5.5), 100 \mathrm{mM}$ phosphoric acid solution ( $\mathrm{pH} 4.8-9.0), 100 \mathrm{mM}$ Tris- $\mathrm{HCl}$ solution $(\mathrm{pH}$ 7.5-9.5), $100 \mathrm{mM}$ carbonic acid solution $(\mathrm{pH}$ 9.0-12.0), relative activities of enzyme in turn is measured by Azocasein Method with the highest enzyme activity being defined as $100 \%$.

\subsubsection{Thermal stability and $\mathrm{pH}$ stability}

Investigate the thermal stability after holding at $20-80^{\circ} \mathrm{C}$ for $10 \mathrm{~min}$ and then quick-cooling in ice bath, as well as $\mathrm{pH}$ stability after storing respectively in the above buffers $(\mathrm{pH} 3.2-12.0)$ and then dialyzing at $4^{\circ} \mathrm{C}$ overnight, by measuring the residual activity of enzyme according to the above-mentioned procedure.

\subsubsection{Determination of kinetic constants}

Use buffer A to formulate azocasein substrates with different concentrations of $0.02 \%, 0.04 \%, 0.08 \%, 0.16 \%, 0.32 \%$, $0.64 \%, 1.25 \%, 2.50 \%$, wherein the amount of enzyme is $1.5 \mathrm{~g}$. Based on Lineweaver-Burk plotting method, $\mathrm{K}_{\mathrm{m}}$ and $\mathrm{V}_{\max }$ are obtained from the enzyme activity of each substrate.

\subsubsection{Effects of inhibitor, metal ions and denaturant on enzyme activity}

Solve inhibitor, metal ions and denaturant respectively in deionized water to obtain concentrated solutions; add the concentrated solutions in $0.5 \mathrm{ml}$ purified enzyme solution (1.0 unit) to formulate the specimen with final concentrations of $1.0 \mathrm{mM}$ and $0.1 \mathrm{mM}$, keep them at $25^{\circ} \mathrm{C}$ for $30 \mathrm{~min}$. Effects of inhibitor, metal ions and denaturant on enzyme activity are investigated by determination of residual enzyme activities of the obtained specimen according to the above-mentioned procedure with the enzyme-free system as blank control and pure enzyme solution as $100 \%$.

\subsubsection{Activation experiment on deactivated protease}

Add $0.5 \mathrm{ml} 2.0 \mathrm{mM}$ EDTA-2Na solution in $0.5 \mathrm{ml}$ purified enzyme solution, keep it at $25{ }^{\circ} \mathrm{C}$ for $30 \mathrm{~min}$; then add various $2.0 \mathrm{mM}$ metallic salt solutions at the amount of $0.5 \mathrm{ml}$, keep it at $25^{\circ} \mathrm{C}$ for $30 \mathrm{~min}$. Effects of various metallic ions on activation of EDTA-2Na-deactivated protease are investigated by determination of the residual enzyme activities of the specimen according to the above-mentioned procedure with EDTA-2Na-free system and the metallic salt-free system as blank controls respectively.

\subsubsection{3 $\mathrm{NH}_{2}$-terminal amino-acid sequence analysis}

$\mathrm{NH}_{2}$-terminal amino-acid sequence analysis is carried out by SHIMADZU PPSQ-10 protein sequence analyzer (Shimadzu of Japan) after electro blotting the purified enzyme based on the method proposed by Matsudaira P (1987, p. 10035-10038). 


\section{Results and discussions}

\subsection{Purification of protease}

After purifying the crude enzyme by ammonium sulfate precipitation (Fraction 2) and two-step anion-exchange chromatography with DEAE-Sephadex A-25 (Figure 1, Fraction 3) and DEAE-Cellulofine A-500 (Figure 2), The specific enzyme activity of the obtained specimen is increased from $25 \mathrm{U} / \mathrm{mg}$ to $12,300 \mathrm{U} / \mathrm{mg}$. The purification fold is 492 , and the recovery rate reaches $23 \%$ (Table 1 ).

From the purification procedure, we can see that ammonium sulfate precipitation is a simple and effective means for initial fractionation of proteins. $80 \%$ protease is recovered and the specific enzyme activity is increased by 120 folds. This is because that ammonium sulfate doesn't affect the enzyme activity; and not only is Hinute SMP-mainly-contained culture medium suitable for E. faecalis TN-9 to develop and produce large amount of protease, but also its residual protein is easy to be removed by ammonium sulfate precipitation process, making it easy for further purification.

Native PAGE analysis shows only one protease band, indicating lack of isozyme in purified protease specimen (Figure 3A); SDS-PAGE analysis also shows only one protease band, indicating an electrophoresis grade for the purification of protease. The subunit molecular weight is calculated as $30 \mathrm{kDa}$. Molecular weight measured by gel chromatography analysis is $69 \mathrm{kDa}$, indicating that the natural state of protease is a dimer consisting of two subunits. Mäkinen et al (1989, p. 3325-3334) isolated and purified a protease with molecular weight of $31.5 \mathrm{kDa}$ from Streptococcus faecalis (OG1-10) and proved it to be a new neutral endoprotease (Gelatinase, EC3.4.24.4).

During purification and while using Tris- $\mathrm{HCl}$ buffer $(100 \mathrm{mM}, \mathrm{pH} 7.5)$, protease is absorbed to DEAE series anion exchange resin adhesive, then eluted with $\mathrm{NaCl}$ solution. However, protease can not be absorbed to DEAE series anion exchange resin adhesive nor CM resin adhesive while using phosphoric acid buffer (100 mM, pH 6.0-7.5) instead. In addition, during PAGE analysis, protease does not show any movement in alanine-acetic acid solution ( $\mathrm{pH} 4.5$ ) in anode/cathode normal-connected NA-1311 Electrolyte Bath; on the other hand, protease moves towards cathode when anode and cathode are reversely connected. This is explained that the protease shows electronegative in Tris- $\mathrm{HCl}$ buffer with $\mathrm{pH}$ higher than 7.0, neutral in phosphoric acid buffer with $\mathrm{pH}$ of 7.0, and electropositive in alanine-acetic acid buffer with $\mathrm{pH}$ of 4.5. Therefore, the isoelectric point of this protease should be between $\mathrm{pH}$ 4.5-pH7.0.

\subsection{Study on the properties of protease}

\subsubsection{Optimal reaction temperature and optimal $\mathrm{pH}$ of the enzyme}

The optimal reaction temperature and optimal $\mathrm{pH}$ of the purified protease are $30^{\circ} \mathrm{C}$ (Figure $4 \mathrm{~A}$ ) and $7.5-8.0$ (Figure 4C) respectively. The optimal $\mathrm{pH}$ of gelatinase isolated from $S$. faecalis (Strain 0G1-10) reported by Mäkinen (1989, p. 3325-3334) is 6-8.

\subsubsection{Thermal stability and $\mathrm{pH}$ stability of the enzyme}

The relative activity of this purified protease is $6.1 \%$ at $0{ }^{\circ} \mathrm{C}$ (Figure $4 \mathrm{~A}$ ), and $65.1 \%$ at $15{ }^{\circ} \mathrm{C}$; while that of cold-adapted protease isolated from psychrophile bacteria Bacillus cereus SYP-A2-3 from glacier is about $6.0 \%$ at $0{ }^{\circ} \mathrm{C}$, and $60 \%$ at $25^{\circ} \mathrm{C}$. It indicates that this protease, with larger low temperature enzyme activity, shows characteristics of cold-adapted enzyme (Shi, Jinsong, 2005, p. 258-263; 2006, p. 72-75). The activity of this purified protease maintains $100 \%$ after heat treatment at $45{ }^{\circ} \mathrm{C}$ for $10 \mathrm{~min}$, drops sharply from $50{ }^{\circ} \mathrm{C}$, and is completely inactivated over $60{ }^{\circ} \mathrm{C}$ (Figure 4B). This indicates that this protease is unstable to heat. The residual activity is over $89 \%$ with pH in the range of 6.0-9.5, and maintains over 70\% in phosphoric acid buffer even with $\mathrm{pH}$ decreased to 4.8 (Figure 4D), demonstrating that this protease is more stable in phosphoric acid buffer.

\subsubsection{Determination of kinetic constants}

Based on Lineweaver-Burk plotting method, $K_{m}$ and $V_{\max }$ are respectively found to be $0.098 \%$ and $72 \mathrm{mg} /(\mathrm{h} \cdot \mathrm{mg}$ ) from the relation between enzyme activity and concentration of azocasein substrate.

3.2.4 Effects of inhibitor, metal ions and denaturant on enzyme activity

As illustrated in Table 2, the purified protease is partially inhibited by $\beta$-mercaptoethanol, Pepstatin A, Chymostatin, DTT and EDTA-2Na, where the inhibiting rate of EDTA-2Na is highest, up to $42 \%$. It is not inhibited by PMSF, TLCK and Leupiptin, inhibited to certain extend by $\mathrm{Hg}^{2+}, \mathrm{Cu}^{2+}, \mathrm{Ag}^{+}, \mathrm{Ni}^{2+}$ and $\mathrm{Co}^{2+}$. However, $\mathrm{Zn}^{2+}, \mathrm{Fe}^{3+}, \mathrm{Mn}^{2+}, \mathrm{Mg}^{2+}, \mathrm{Fe}^{2+}$ and IAA increase enzyme activity (Table 3). In addition, EDTA-2Na-deactivated enzyme (apoenzyme) can be activated by $\mathrm{Zn}^{2+}$, indicating that $\mathrm{Zn}^{2+}$ is the main metal ion to catalyze chemical reactions begins with the binding of the substrate to the active site on the enzyme. Meanwhile, the protease is inhibited by the inhibitor of aspartic acid Pepstatin A, suggesting that aspartic acid is abundant at the active site on the enzyme and active in catalyzing chemical reactions.

3.2.5 $\mathrm{NH}_{2}$-terminal amino-acid sequence analysis 
$10 \mathrm{NH}_{2}$-terminal amino-acid starting with $\mathrm{V}$ (Val) sequence (VGSEVTLKNS) are proved. By using FASTA sequence similarity analysis with NCBI database, the analysis are in accordance with that of gelatinase (EC 3.4.24.4) isolated from S. faecalis (Strain OG1-10) (Pirkko-Liisa, Mäkinen, 1989, p. 3325-3334) and Cocolysin (EC 3.4.24.30) (Pirkko-Liisa, Mäkinen, 1994, p. 981-985). It suggests that the metalloprotease isolated from E. faecalis TN-9 is a gelatinase. In 1994, Mäkinen et al isolated and purified Coccolysin (EC3.4.24.30) from E. faecalis (OG1-10) and concluded that Coccolysin is one of Gelatinase based on amino-acid sequence analysis. Although Pirkko-Liisa, Mäkinen et al (1989, p. 3325-3334; 1994, p. 981-985) isolated and determined gelatinase (EC 3.4.24.4) and cocolysin (EC 3.4.24.30) sequentially, the study on the characteristics of cold-adapted metalloprotease isolated from E. faecalis hasn't been reported so far.

\section{Conclusion}

This paper illustrated the purification process and common characteristics of extracellular protease isolated from lactic acid bacteria E. faecalis TN-9 from deep sea water. The electrophoresis-grade metalloprotease acquired by 3-step purification process has a specific activity $12,300 \mathrm{U} / \mathrm{mg}$, a recovery rate $23 \%$, a subunit molecular weight $30 \mathrm{kDa}$ and Native molecular weight $69 \mathrm{kDa}$ and an isoelectric point is between $\mathrm{pH} 4.5$ and $\mathrm{pH} 7.0$. These properties indicate that the protease is a metalloprotease with $\mathrm{Zn}^{2+}$-depent active site. The protease has $10 \mathrm{~N}$-terminal sequence (VGSEVTLKNS) the same as Gelatinase (EC3.4.24.4) and Coccolysin, indicating the isolated protease is one of Gelatinase for classification point of view. The purified protease has a relative activity $6.1 \%$ at $0{ }^{\circ} \mathrm{C}$, a maximum relative activity at $30^{\circ} \mathrm{C}$ and between $\mathrm{pH} 7.5$ and $\mathrm{pH}$ 8.0. The activation protease is in the most stable state between $\mathrm{pH}$ 6.0 and $\mathrm{pH} 9.5$ and at temperature below $45^{\circ} \mathrm{C}$, drops sharply above $50{ }^{\circ} \mathrm{C}$, is completely inactivated above $60{ }^{\circ} \mathrm{C}$. Meanwhile, phosphoric acid buffer is more beneficial to the storage and activation of this protease. Km and Vmax of purified protease acting on azocasein are $0.098 \%$ and $72 \mathrm{mg} /(\mathrm{h} \cdot \mathrm{mg})$ respectively.

The purified metalloprotease exhibits certain features of cold-adapted enzyme, especially in low-temperature catalyst and thermal instability. Therefore it is concluded as a cold-adapted metalloprotease. It is shown by an incomplete literature search that this is the first report on the characteristics of cold-adapted metalloprotease isolated from lactic acid bacterium in deep sea so far. Atsushi Hayashi et al (2007, p. 58-64) believes that E. faecalis TN-9 most likely comes from muddy cold seabed or excrement of psychrophilic fish at the bottom of deep sea. Our study further validates the conclusion. Cold-adapted enzymes in many research reports come from psychrophilic bacteria in extreme cold environments such as glacier, marine environment and alike. Most psychrophilic bacteria secrete cold-adapted enzymes. Gerday C et al (2000, p. 103-107) believes that as dominating species of cold ecosystem, cold-adapted microorganisms live widely in polar region, glacier, ice sea, deep sea and other year-around cold environments. Cold-adapted microorganisms can produce some efficient cold-adapted enzymes to maintain normal metabolism and other complex functions.

Application of cold-adapted protease isolated from bacteria has bright future in food industry. It can improve the quality, stability and solubility of food. It could be produced in industrial scale, serving as an inexpensive and abundant enzyme source., It is generally toxic free, capable of processing food at low temperature and is generally free of side effect as the enzymes deactivate rapidly at moderate temperature (Ryoma Miyake, 2007, p. 4849-4856; Wang, Yujing, 2004 , p. 8-15; Nakagawa T, 2004, p. 383-387; Gu, Jing, 2002). The purified cold-adapted protease studied in this paper has a maximum activity at $30^{\circ} \mathrm{C}$, and is deactivated at $60^{\circ} \mathrm{C}$ within only $10 \mathrm{~min}$, therefore meets the enzyme-processing requirements for food at low temperature. In addition, the safety of the oral administration of E. faecalis TN-9 has been proved. Not only can the purified enzyme from culture media be applied to food industry, but also is the culture media itself and bacterium strain applied in food industry directly. In all, the application of lactic acid bacteria E. faecalis TN-9 and the cold-adapted metalloprotease from it has promising future in food industry.

\section{References}

Atsushi Hayashi, Takashi Shimada, Hiroyasu Onaka \& Tamotsu Furumai. (2007). Isolation and phenotypic characterization of enterococci from the deep-seawater samples collected in Toyama Bay. Japanese Journal of Lactic Acid Bacteria, 18(2), 58-64.

Chie Motonaga, Atsushi Hayashi, Masatoshi Kondoh, Mariko Okamori, Takashi Shimada \& Tamotsu Furumai. (2007). Toxicological studies on Enterococcus faecalis TN-9 isolated from Deep-seawater. Pharmacometrics, 73(1/2), 191-196.

Denner E B, Mark B, Busse H J, Turkiewicz M \& Lubitz W. (2001). Psychrobacter proteolyticus sp. nov., a psychrotrophic, halotolerant bacterium isolated from the Antarctic krill Euphausia superba Dana, excreting a cold-adapted metalloprotease. Syst Appl Microbiol., 4(1), 44-53.

Gerday C, Aittaleb M, Bentahir M, Chessa J P, Claverie P, Collins T, D'Amico S, Dumont J, Garsoux G, Georlette D, Hoyoux A, Lonhienne T, Meuwis M A \& Feller G. (2000). Cold-adapted enzymes: from fundamentals to biotechnology. Trends Biotechnol, 18(3), 103-107.

Hagihara B, Matsubara H, Nakai M \& Okunuki K. (1958). Crystalline bacterial proteinase I, preparation of crystalline 
protease of bacillus subtilis. J. Biochem., 45(3), 185-194.

Jing, Gu, Feng, Jing, Kong, Jian \& Ma, Guirong. (2002). Research progress on metalloproteinases from microorganisms. Progress in Biotechnology, 22(1).

Lowry O H, Rosebrough N J, Farr A L \& Randall R J. (1951). Protein measurement with the Folin phenol reagent. $J$. Biol. Chem., 193, 265-275.

Matsudaira P. (1987). Sequence from picomole quantities of proteins electroblotted onto polyvinylidene difluoride membranes. J Biol Chem, 262, 10035-10038.

Miyamoto K, Tsujibo H, Nukui E, Itoh H, Kaidzu Y \& Inamori Y. (2002). Isolation and characterization of the genes encoding two metalloproteases (MprI and MprII) from a marine bacterium, Alteromonas sp. strain O-7. Biosci Biotechnol Biochem., 66(2), 416-421.

Nakagawa T, Nagaoka T, Taniguchi S, Miyaji T \& Tomizuka N. (2004). Isolation and characterization of psychrophilic yeasts producing cold-adapted pectinolytic enzymes. Lett Appl Microbiol., 38(5), 383-7.

Nushin Aghajari, Filip Van Petegem, Vincent Villeret, Jean-Pierre Chessa, Charles Gerday, Richard Haser \& Jozef Van Beeumen. (2003). Crystal structures of a psychrophilic metalloprotease reveal new insights into catalysis by cold-adapted proteases. Proteins, 50(4), 636-647.

Pirkko-Liisa Mäkinen \& Kauko K Mäkinen. (1994). The enterococcus faecalis extracellular metallendopeptidase (EC3.4.24.30; coccolysin) inactivates human endothelin at bonds involving hydrophobic amino acid residues. Biochem..

Biophysi. Res. Commun., 200(2), 981-985.

Pirkko-Liisa Mäkinen, Don B Clewell, Florence An \& Kauko K Mäkinen. (1989). Purification and substrate specificity of a strongly hydrophobic extracellular metalloendopeptidase ("Gelatinase") from streptococcus faecalis (Strain 0G1-10). J. Biol. Chem., 264(6), 3325-3334.

Reisfeld R A, Lewis U J \& Williams D E. (1962). Disk electrophoresis of basic proteins and peptides on polyacrylamide gels. Nature, 195: 281-283.

Ryoma Miyake, Jun Kawamoto, Yunlin Wei, Masanari Kitagawa, Ikunoshin Kato, Tatsuo Kurihara \& Nobuyoshi Esaki. (2007). Construction of a low-temperature protein expression system using a cold-adapted bacterium, Shewanella sp. Strain Ac10, as the host. Applied and Environmental Microbiology, 73 (15), 4849-4856.

Shi, Jinsong, Wu, Qifan, Xu, Zhenghong \& Tao, Wenyi. (2005). Identification of psychrotrophs SYP-A2-3 producing cold-adapted protease from the No. 1 Glacier of China and study on its fermentation conditions. Acta Microbiol Sin., 45(2), 258-263.

Shi, Jinsong, Xu, Zhenghong, Wu, Qifan \& Tao, Wenyi. (2006). Purification and characterization of cold-adapted protease produced by psychrotroph of glacier environment. Chin J Appl Environ Biol., 12(1), 72-75.

Thomas J B, Gary W S \& James H H. (1986). Activition of intracellular serine protease in bacillus subtillis cells during sporulation. J. Bacteriol., 165(1), 139-145.

Wang, Yujing, Zhang, Manping, Sun, Mi, Wang, Yuejun, Xie, Hongguo \& Chen, Chunguang. (2004). The chemical characteristics of marine low-temperature alkaline protease (YS-80-122). Transactions of Oceanology and Limnology, 1, $8-15$.

Weber K \& Osborn M. (1969). The reliability of molecular weight determination by dodecyl sulfate-polyacrylamide gel electrophoresis. J. Biol. Chem., 244, 4406-4412.

Table 1. Summary of purification of protease

\begin{tabular}{|c|c|c|c|c|c|}
\hline Purification steps & $\begin{array}{c}\text { Total activity } \\
(\mathrm{U})\end{array}$ & $\begin{array}{c}\text { Total protein } \\
(\mathrm{mg})\end{array}$ & $\begin{array}{c}\text { Specific activity } \\
(\mathrm{U} / \mathrm{mg})\end{array}$ & Purification (fold) & $\begin{array}{c}\text { Recovery } \\
(\%)\end{array}$ \\
\hline Culture supernatant & $3.5 \times 10^{5}$ & 14,265 & 25 & 1 & 100 \\
\hline Ammonium sulfate & 2.8 & 95 & 2,950 & 118 & 80 \\
\hline DEAE-Sephadex A-25 & 0.8 & 12.8 & 6,250 & 250 & 23 \\
\hline DEAE-Cellulofin A-500 & 0.8 & 6.5 & 12,300 & 492 & 23 \\
\hline
\end{tabular}


Table 2. Effects of inhibitor, denaturant and reducing agent on the activity of protease

\begin{tabular}{|c|c|c|}
\hline Compound & Concentration & Relative activity (\%) \\
\hline \multicolumn{3}{|l|}{ Inhibitor } \\
\hline None & 0 & 100 \\
\hline PMSF & $10 \mu \mathrm{g} / \mathrm{ml}$ & 105 \\
\hline TLCK & $10 \mu \mathrm{g} / \mathrm{ml}$ & 100 \\
\hline Leupiptin & $10 \mu \mathrm{g} / \mathrm{ml}$ & 100 \\
\hline PCMB & $10 \mu \mathrm{g} / \mathrm{ml}$ & 105 \\
\hline $\mathrm{ICH}_{2} \mathrm{COOH}$ & $1.0 \mathrm{mM}$ & 98 \\
\hline EDTA-2Na & $0.1 \mathrm{mM}$ & 58 \\
\hline Pepstatin A & $10 \mu \mathrm{g} / \mathrm{ml}$ & 81 \\
\hline n-Octyl alcohol & $1.0 \mathrm{mM}$ & 99 \\
\hline Chymostatin & $10 \mu \mathrm{g} / \mathrm{ml}$ & 91 \\
\hline IAA & $10 \mu \mathrm{g} / \mathrm{ml}$ & 124 \\
\hline AEBSF & $10 \mu \mathrm{g} / \mathrm{ml}$ & 100 \\
\hline Phosphoramidon & $10 \mu \mathrm{g} / \mathrm{ml}$ & 119 \\
\hline Antipain & $10 \mu \mathrm{g} / \mathrm{ml}$ & 100 \\
\hline $\mathrm{BHH}$ & $10 \mu \mathrm{g} / \mathrm{ml}$ & 100 \\
\hline \multicolumn{3}{|c|}{ Denaturant and reducing agents } \\
\hline None & 0 & 100 \\
\hline SDS & $1.0 \mathrm{mM}$ & 102 \\
\hline Urea & $1.0 \mathrm{mM}$ & 101 \\
\hline DTT & $10 \mu \mathrm{g} / \mathrm{ml}$ & 96 \\
\hline$\beta$-mercaptoethanol & $1.0 \mathrm{mM}$ & 68 \\
\hline
\end{tabular}


Table 3. Effects of metal ions on the activity of protease

\begin{tabular}{|c|c|c|}
\hline \multirow{3}{*}{ Metal ion } & \multicolumn{2}{|c|}{ Relative activity (\%) } \\
\hline & \multicolumn{2}{|c|}{ Concentration } \\
\hline & $1.0 \mathrm{mM}$ & $0.1 \mathrm{mM}$ \\
\hline None & 100 & 100 \\
\hline $\mathrm{Zn}^{2+}$ & 116 & 109 \\
\hline $\mathrm{Fe}^{3+}$ & 112 & 100 \\
\hline $\mathrm{Mn}^{2+}$ & 107 & 103 \\
\hline $\mathrm{Mg}^{2+}$ & 106 & 100 \\
\hline $\mathrm{Fe}^{2+}$ & 104 & 100 \\
\hline $\mathrm{Co}^{2+}$ & 78 & 88 \\
\hline $\mathrm{Ni}^{2+}$ & 74 & 82 \\
\hline $\mathrm{Ag}^{+}$ & 72 & 82 \\
\hline $\mathrm{Cu}^{2+}$ & 27 & 51 \\
\hline $\mathrm{Hg}^{2+}$ & 8 & 10 \\
\hline
\end{tabular}

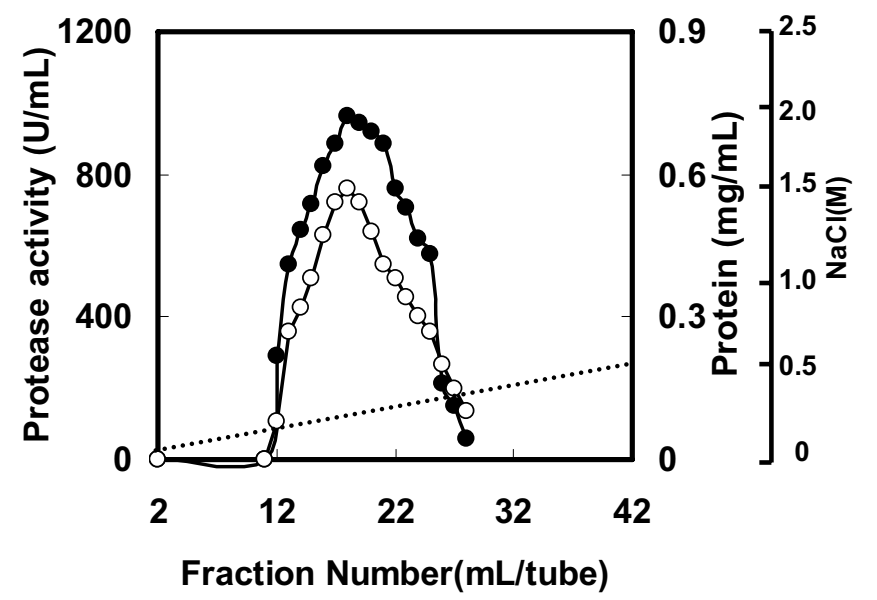

Figure 1. Column chromatography of protease on DEAE-Sephadex A-25

The enzyme solution (Fraction 2) was applied to a column $(26 \times 180 \mathrm{~mm})$ of DEAE-Sephadex A-25 equilibrated with buffer A. The column was washed with $450 \mathrm{ml}$ buffer $\mathrm{A}$, then proteins were eluted with a linear gradient of 0 to $2.5 \mathrm{M}$ $\mathrm{NaCl}$ solved in $720 \mathrm{ml}$ buffer A. Fractions of $6.0 \mathrm{ml}$ were collected at flow rate of $60 \mathrm{ml} / \mathrm{h}$. Protein concentration and protease activities were assayed.

- represents enzyme activity; o represents protein concentration; $\cdots$ represents $\mathrm{NaCl}$. 


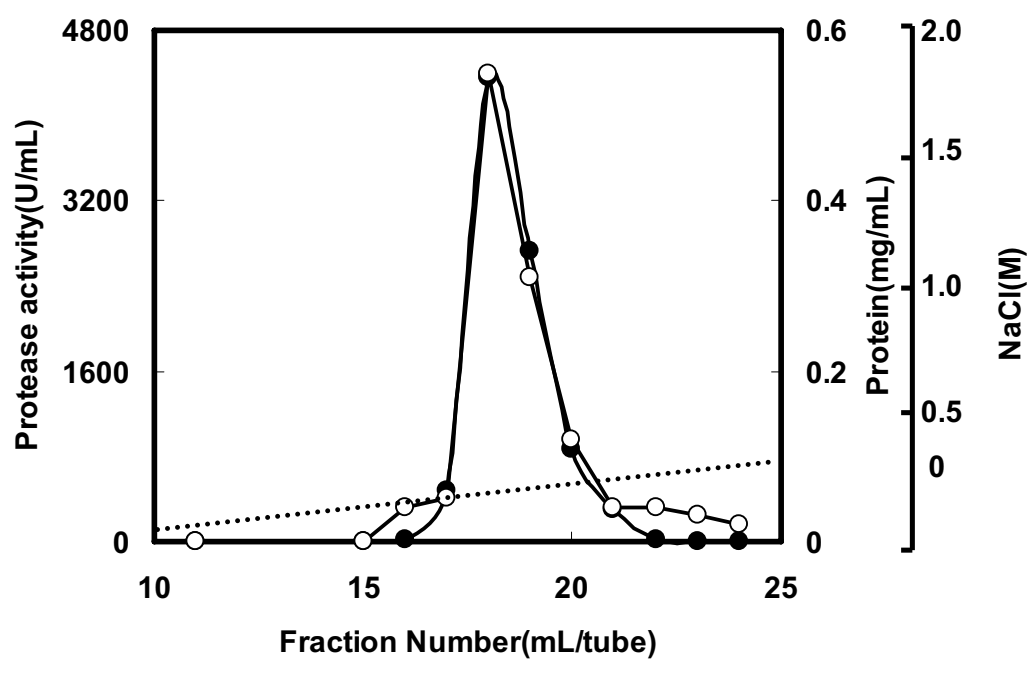

Figure 2. Column chromatography of protease on DEAE-Cellulofine A-500

The enzyme solution (Fraction 3) was applied to a column $(26 \times 180 \mathrm{~mm})$ of DEAE-Cellulofine A-500 equilibrated with buffer A. The column was washed with $450 \mathrm{ml}$ buffer A, then proteins were eluted with a linear gradient of 0 to $2.0 \mathrm{M}$ $\mathrm{NaCl}$ solved in $720 \mathrm{ml}$ buffer A. Fractions of $3.0 \mathrm{ml}$ were collected at flow rate of $40 \mathrm{ml} / \mathrm{h}$. Protein concentration and protease activities were assayed.

- represents enzyme activity; $\circ$ represents protein concentration; $\cdots$ represents $\mathrm{NaCl}$.

A

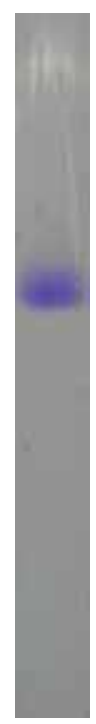

B

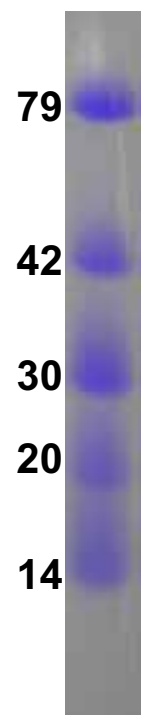

(1)

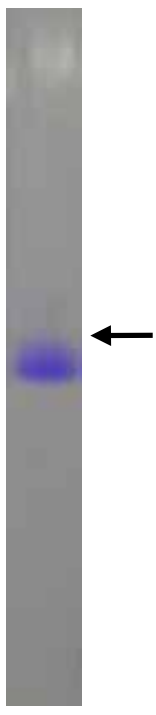

(2)

Figure 3. Native PAGE (A) and SDS-PAGE (B) of protease.

A: Native PAGE, the purified enzyme $(5.0 \mu \mathrm{g})$ was run on a $7.5 \%(\mathrm{w} / \mathrm{v})$ gel with $\mathrm{pH} 4.0$ at $2.5 \mathrm{~mA} /$ tube for $3.5 \mathrm{~h}$ in a running buffer $(\mathrm{pH} 4.5)$ of $\beta$-alanine-acetic acid.

B: SDS-PAGE, the purified enzyme $(5.0 \mu \mathrm{g})$ denatured with SDS was run on a $7.5 \%(\mathrm{w} / \mathrm{v})$ gel containing $0.10 \%(\mathrm{w} / \mathrm{v})$ SDS at $6.0 \mathrm{~mA} /$ tube for $3.0 \mathrm{~h}$ in a running buffer $(\mathrm{pH} 7.2)$ of $0.10 \%(\mathrm{w} / \mathrm{v}) \mathrm{SDS}-0.10 \mathrm{M}$ sodium phosphate.

The gels were stained with $0.25 \%$ (w/v) Coomassie Brilliant Blue R-250 in a solvent mixture of ethanol, acetic acid and water at the ratio of 9:2:9.

$\mathrm{B}(1)$ : molecular weight markers: Lysozyme $(14,000)$, trypsin inhibitor $(20,000)$, carbonic anhydrase $(30,000)$, aldolase $(42,000)$ and bovine serum albumin $(79,000)$. 
$\mathrm{B}(2)$ : purified enzyme.

$$
\text { A }
$$

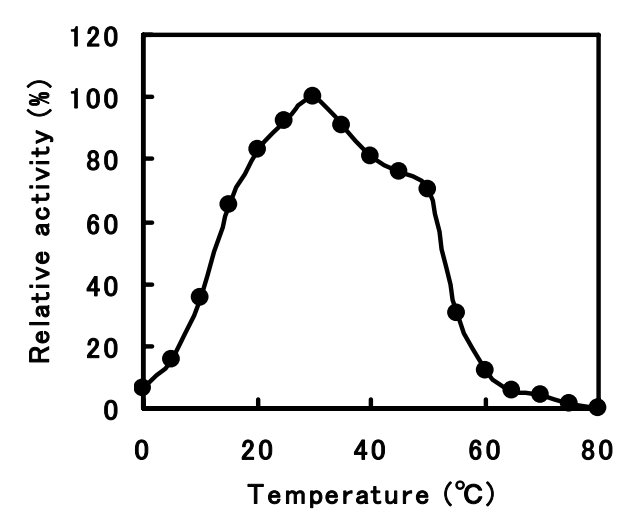

C

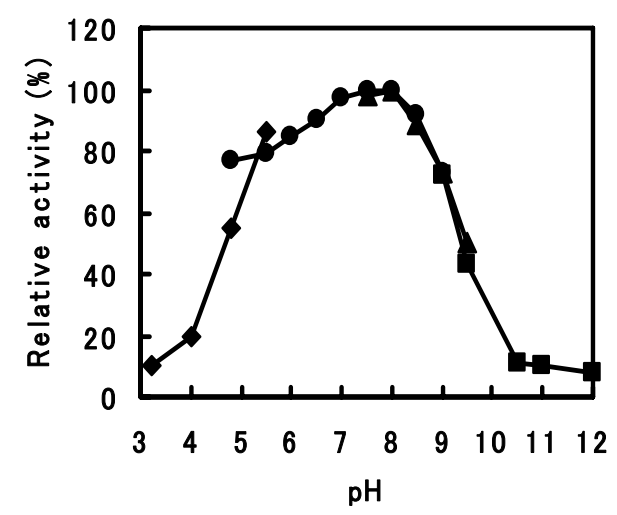

B

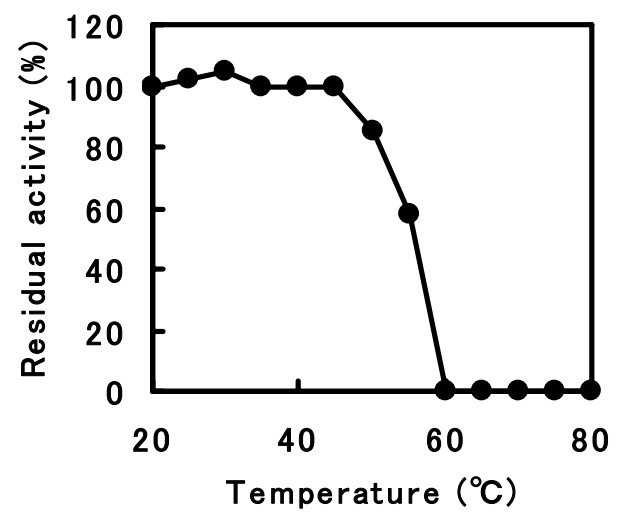

D

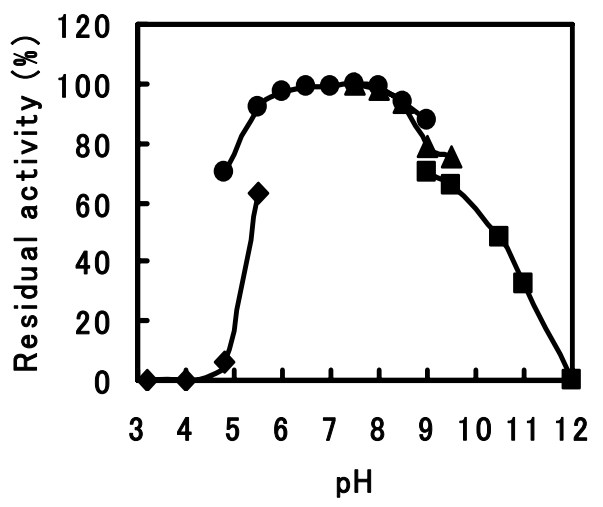

Figure 4. Effects of temperature on activity (A) and stability (B), and effects of $\mathrm{pH}$ on activity (C) and stability (D) At the amount of $1.25 \%(\mathrm{w} / \mathrm{v})$, Azocasein assay was used for characterization of the protease.

A: Protease activity was measured at $0-80{ }^{\circ} \mathrm{C}$ with $\mathrm{pH}$ of 7.5 for $10 \mathrm{~min}$.

B: After heat treatment at various temperatures $\left(20-80^{\circ} \mathrm{C}\right)$ with $\mathrm{pH}$ of 7.5 for $10 \mathrm{~min}$.

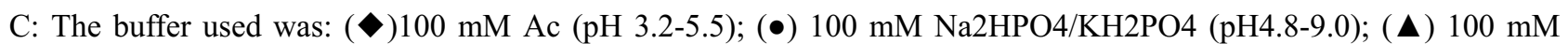
Tris/ $\mathrm{HCl}(\mathrm{pH} 7.5-9.5)$ and (-) $100 \mathrm{mM} \mathrm{NaCO} / \mathrm{NaHCO}_{3}(9.0-12.0)$. Maximal activity of protease was defined as $100 \%$. Enzyme assay was carried out at $30^{\circ} \mathrm{C}$ for $10 \mathrm{~min}$.

D: $\mathrm{pH}$ of the purified protease was adjusted in different buffers: $(\diamond) 100 \mathrm{mM} \mathrm{Ac}(\mathrm{pH} 3.2-5.5) ;(\bullet) 100 \mathrm{mM}$

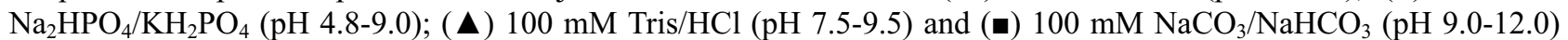
buffer. The enzyme was incubated at $4^{\circ} \mathrm{C}$ overnight, then the residual activity of protease was measured at $\mathrm{pH} 7.5$ for 10 min. 